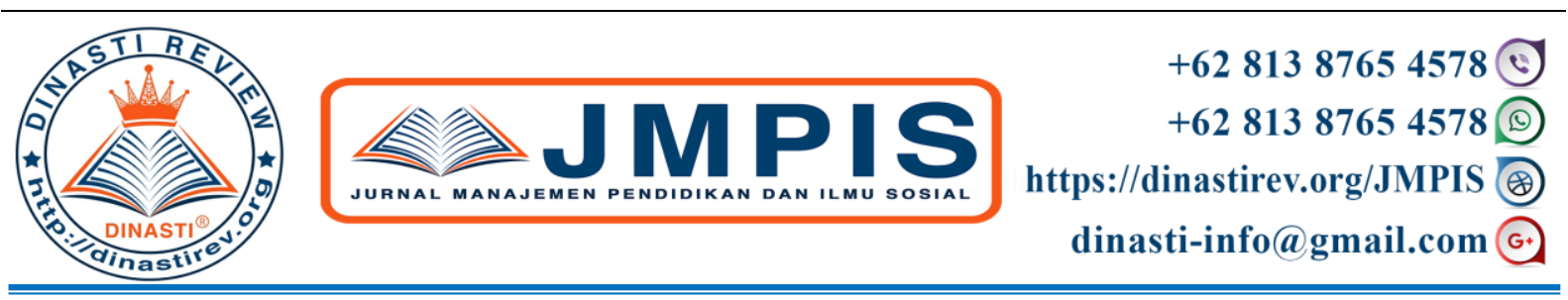

\title{
NOBLE INDUSTRY: PENDIDIKAN MULTIKULTURAL PESANTREN DAN BOARDING SCHOOL (STUDI TERHADAP PESANTREN SALAFY DAN MADRASAH BERASRAMA NON-PESANTREN DI JAMBI)
}

\author{
Maisah $^{1)}$, M. Kamal'), Irjus Indrawan ${ }^{3)}$, Ade Julianza ${ }^{4)}$, Soni Yuda Ariyanto ${ }^{5)}$ \\ ${ }^{1)}$ UIN Sulthan Thaha Saifuddin Jambi, Jambi Indonesia \\ ${ }^{2}$ )Madrasah Aliyah Negeri Insan Cendekia, Jambi Indonesia \\ ${ }^{3}$ Universitas Islam Indragiri, Riau Indonesia \\ ${ }^{4,5)}$ Institut Agama Islam Yasni Bungo, Jambi Indonesia
}

\begin{tabular}{|c|c|}
\hline $\begin{array}{l}\text { ARTICLE INFORMATION } \\
\text { Received: } 12 \text { Maret } 2020 \\
\text { Revised: } 17 \text { Maret } 2020 \\
\text { Issued: } 23 \text { Maret } 2020 \\
\text { Corresponding author: } \\
\text { Maisah }\end{array}$ & $\begin{array}{l}\text { Abstrak: Penelitian ini mejelaskan model pendidikan } \\
\text { multikultural pada madrasah di kota Jambi, penelitian } \\
\text { ini diharapkan mampu menjadi twanan model } \\
\text { pendidikan mutikultural agar dapat diaplikasikan di } \\
\text { kominitas masyarakat lainnya terutama dalam } \\
\text { mencegah ancaman radikalisme. Dengan menggunakan } \\
\text { model kualitatif, didapatkan hasil penelitian sebagai } \\
\text { berikut: pertama pola internalisasi tradisi di pondok } \\
\text { sangat di pengaruhi oleh nilai-nilai karakter sosial } \\
\text { siswa yang ada di pondok pesantren yang dapat } \\
\text { ditanamkan pada pendidikan boarding shcool baik di } \\
\text { pesantren maupun di madrasah, kedua, pola } \\
\text { tranformasi dimensi multikultural di pendidikan } \\
\text { pesantren mempunyai ciri khas memberikan } \\
\text { pengetahuan mengenai ilmu alat/metode, sebagai kunci } \\
\text { untuk membaca dan memahami ilmu agama yang lebih } \\
\text { mendalam, hal ini karena pemahaman mengenai ajaran } \\
\text { agama dilandasi oleh pemahaman metodologis } \\
\text { terhadap ilmu, pendidikan multikultural merupakan } \\
\text { proses pengembangan sikap dan tata laku seseorang } \\
\text { atau sekelompok orang dalam usaha mendewasakan } \\
\text { manusia melalui upaya pengajaran, pelatihan, proses, } \\
\text { perbuatan, dan cara-cara mendidik yang menghargai } \\
\text { pluralitas dan heterogenitas secara humanistik } \\
\text { Kata Kunci: Pendidikan Multikultural, Pesantren Dan } \\
\text { Boarding School }\end{array}$ \\
\hline
\end{tabular}

\section{PENDAHULUAN}

Perkembangan pendidikan keagamaan khususnya pendidikan Islam di Indonesia terus meluas sampai ke pelosok daerah dan mengalami perubahan dan pergeseran yang cukup signifikan. Sejarah perubahan dan perkembangan pendidikan Islam mencatat munculnya sekolah dan madrasah dengan mencantumkan karakteristiknya masing-masing, misalnya, 
madrasah model, sekolah unggulan, sekolah bertaraf internasional, sekolah Islam terpadu, pondok pesantren, boarding school dan lain sebagainya, walaupun dalam kurun waktu terakhirbeberapa diantaranya mengalami perubahan secara yuridis. Pencantuman label pada nama sekolah tersebut berimplikasi pada sistem pembelajaran dan kultur pendidikan yang khas.

Berdasarkan pengalaman penulis saatnyantri di beberapa pondok pesatren di Jawa Timurpada tahun (1991-1996), baik yang salafy maupun modern, diketahui bahwa pondok pesantren memiliki karakteristik unik dari lembaga-lembaga pendidikan lainnya. Salah satu keunikan yang dimiliki pesantren adalah sistem pembelajaranya yang masih tetap mempertahankan sistem pendidikan tradisional (salaf), seperti mengaji "kitab kuning" atau kitab-kitab klasik (kutub al-turast) dengan cara sorogan, wetonan-bandongan, mengaji ilmu bahasa Arab; nahwu, shorof,balaghah dengan model penghafalan syair-syair/nazom, seperti nazom Imrithy dan nazom alfiyah ibnu Malik, serta program diskusi ilmiah (bahtsu almasa'il) tentang pembahasan masalah sosial keagamaan seperti fiqhibadah maupun mu'amalahdan lain sebagainya.

Asrama sebagai tempat tinggal peserta didik merupakan fakta sosial yang sangat menarik untuk diteliti.Hal ini disebabkan karena keberadaan siswa di asrama membentuk kelompok, komunitas atau masyarakat baru yang terbentuk atas konsensus dan prosesnya sangat cepat, berbeda dengan masyarakat pada bangsa atau etnis tertentu yang pada umumnya memerlukan jangka waktu yang sangat lama. Selain itu, anggota masyarakat yang baru terbentuk ini pada umumnya memiliki latar budaya dan struktur masyarakat yang berbeda-beda serta memiliki karakter yang beragam.

Menurut (Papworth, 1998:6) ada 4 keunikan sekaligus keistimewaan tersendiri sistem sekolah berasrama dibanding sekolah biasa yang siswanya tinggal bersama orang tuanya di rumah. Pertama, kehidupan sekolah asrama melibatkan sistem regulasi yang kompleks dan penjadwalan kegiatan yang ketat, rutinitas harian siswa - bekerja, bermain, dan tidur - dan berbagai kegiatan sehari-hari yang dilakukan, di bawah pengawasan konstan sehingga terbentuk perilaku, partisipasi dan dapat menyelesaikan tugas/pekerjaan rumah dengan baik. Kedua; sekolah berasrama memiliki identitas kolektif melalui tradisi kebersamaan dalam setiap melakukan kegiatan sekolah seperti kompetisi olahraga, korps intra-sekolah dan antarsekolah. Ketiga; lingkungan tempat tinggal sekolah berasrama menyediakan konteks ekologis tertentu, yang memungkinkan asrama menjadi sarana interaksi sosial siswa dengan teman sebaya atau yang lebih senior seperti staf kepegawaiaan. Interaksi social ini berdampak positif pada pertumbuhan dan perkembangan siswa. Keempat; siswa pada sekolah berasrama biasanya menghabiskan lebih banyak waktu dengan guru, pelatih, dan staf sekolah lainnya (misalnya; staf asrama), dan memiliki kesempatan lebih besar untuk mengembangkan bimbingan atau hubungan pribadi dengan mereka daripada siswa sekolah regular yang tidak berasrama.

Pondok pesantren merupakan lembaga pendidikan yang sudah ada dari sebelum zaman kemerdekaan yang dipimpin oleh seorang atau beberapa orang kyai dan para ustazd dan ustadzah. Kehadirannya di bumi Nusantara sebagai wadah mencerdaskan masyarakat Indonesia dalam perspektif agama dan juga nasionalisme. Semangat institusi pendidikan pondok pesantren sampai saat ini masih terasa meskipun pendidikan formal sudah banyak didirikan.

Pada awal berdirinya, kegiatan pondok pesantren masih sangat sederhana. Berawal dari kegiatan-kegiatan di masjid yang kemudian untuk santri-santrinya didirikanlah sebuah pondok sebagai tempat tinggal. Pada tahap ini pondok pesantren belum dipandang sebagai bagian dari sistem pendidikan nasional, tetapi merupakan lembaga pendidikan otonom milik masyarakat. Pesantren, meskipun dalam perjalanannya dibawah pengawasan Menteri Agama namun masih terkesan terdikotomi diluar sistem pendidikan nasional. Hal ini disebabkan karena kenyataannya bahwa sistem pendidikan pesantren didominasi oleh muatan-muatan 
agama, menggunakan kurikulum yang belum terstandar, memiliki struktur yang tidak seragam, dan memberlakukan manajemen yang kurang dapat dikontrol oleh pemerintah.

Menghadapi kenyataan tersebut di atas, para stakeholders berusaha melakukan formalisasi dan strukturisasi madrasah dan pondok pesantren. Formalisasi ditempuh dengan menegerikan sejumlah madrasah dengan kriteria tertentu yang diatur pemerintah, di samping mendirikan madrasah-madrasah negeri yang baru. Sedangkan strukturisasi dilakukan dengan mengatur perjenjangan dan perumusan kurikulum yang cenderung sama dengan perjenjangan dan kurikulum sekolah-sekolah di bawah Departemen Pendidikan dan Kebudayaan (Dirjen Pendis, 2016:60).

Perkembangan selanjutnya, untuk madarasah diterbitkan Surat Keputusan Bersama (SKB) Tiga Menteri yang menyepakati mata pelajaran agama Islam sebagai dasar yang diberikan dilembaga pendidikan sekurang-kurangnya 30\% disamping mata pelajaran umum. Sedangkan untuk pesantren, baru-baru ini telah terbit Undang-Undang Pesantren Nomor 18 Tahun 2019 yang memvalidasi rumusan norma hukum secara optimal sesuai dengan karakteristik dan kekhasan Pesantren.

Melalui Undang-Undang tentang Pesantren, penyelenggaraan pendidikan pesantren diakui sebagai bagian dari penyelenggaran pendidikan nasional. Pesantren merupakan lembaga yang berbasis masyarakat dan didirikan oleh perseorangan, yayasan, organisasi masyarakat Islam dan/atau masyarakat yang menanamkan keimanan dan ketakwaan kepada Allah Swt., menyemaikan akhlak mulia, serta memegang teguh ajaran Islam rahmatan lil'alamin yang tercermin dari sikap rendah hati, toleran, keseimbangan, moderat, dan nilai luhur bangsa Indonesia lainnya melalui pendidikan, dakwah Islam, keteladanan, dan pemberdayaan masyarakat dalam kerangka Negara Kesatuan Republik Indonesia.

Banyak ulasan tentang pesantren sepanjang rentang sejarah, di sisi lain terdapatpula pendidikan keagamaan dengan pola berasrama non-pesantren atau dikenal dengan sebutan boarding school. Sekolah atau madrasah boarding school berbeda dengan pondok pesantren. Fenomena madrasah berasrama (boarding school) masih tergolong baru di Indonesia, sebab sebelumnya lembaga pendidikan yang berasrama pada umumnya terdapat pada pondok pesantren, atau setidaknya lembaga pendidikan khusus yang dipersiapkan untuk mencapai standar keterampilan tertentu yang memang sangat membutuhkan lingkungan yang terpadu. Sementara itu, untuk sekolah atau madrasah umum, lazimnya tidak berasrama.

Berbicara tentang pendidikan madrasah dengan pola berasrama, baik pondok pesantren maupun madrasah boarding school dengan kehidupan sosio-kultural dan multi etnis, tidak akan lepas dari tema agama dan budaya dalam bingkai pendidikan Islam.Indonesia meski memiliki populasi muslim terbesar di dunia adalah Negara Kesatuan Republik Indonesia, negara yang berlandaskan pada asas Ketuhanan Yang Maha Esa, negara yang mendukung toleransi antar umat beragama, negara yang berbhinneka tunggal ika.

Madrasah pondok pesantren maupun madrasah berasrama non-pesantren (boarding school) memilki peluang yang besar dengan segala keunikan dan potensinya untuk membentuk peserta didiknya sebagai insan yang mampu memahami agama dengan baik dan mendalam, mampu menumbuhkan kesadaran bahwa keragaman pada hakikatnya bukan untuk dipertentangkan namun sebaliknya harus dihormati (Dirjen Pendis, 2016:2), sehingga potensi terbesar mewujudkannoble industry (industri mulia) pendidikan multikultural ada pada lembaga pendidikan pesantren dan boarding school.

Banyak lembaga pendidikan yang menerapkan sistem pendidikan berasrama, baik pondok pesantren maupun boarding schooldidasarkan atas pertimbangan untuk mencapai tujuan pendidikan yang lebih utuh, yang mencakup cipta, rasa, karsa, dan karya sehingga menghasilkan lulusan yang tidak hanya unggul dalam berpikir tetapi juga berkepribadian mulia. Pemikiran tersebut muncul sebagai konsekuensi dari kenyataan bahwa pada umumnya sekolah non-asrama terkonsentrasi pada kegiatan-kegiatan akademik sehingga banyak aspek lain dari kehidupan peserta didik yang tidak tersentuh. Hal ini terjadi karena keterbatasan 
waktu yang ada dalam pengelolaan program pendidikan pada sekolah non-asrama. Sebaliknya, pendidikan berasrama dapat menerapkan program pendidikan yang komprehensif-holistik mencakup keagamaan, pengembangan akademik, life skills (soft skills dan hard skills), berwawasan kebangsaandan membangun wawasan global.

Namun demikian, pendidikan keagamaan berwawasan kebangsaandan berwawasan global tidak boleh difahami secara bebas dan liberalsebagai pluralisme agama dalam pengertian "semua agama adalah sama benarnya", tetapi pluralism agama diterjemahkan sebagai suatu realitas yang harus diterima bahwa manusia hidup bersama dalam keberbedaan budaya maupun agama.

Fatwa Majelis Ulama Indonesia (MUI) mengharamkan pluralisme agama dalam pengertian bahwa "semua agama adalah sama". Menurut MUI, implikasi pemahaman seperti ini akan mengubah aspek-aspek baku dari suatu ajaran dengan mengikuti ajaran lain, sebab hal yang demikian itu tidak dikehendaki oleh ajaran manapun, tetapi teologi inklusif dan pluralisme agamaharus dimaknai dan dikembangkan untuk mendukung dialog antar agama (Zainuddin, 2013:8).

\section{KAJIAN PUSTAKA}

\section{Industri Mulia (noble industry)}

Menggunakan istilah (Muhaimin, 2009: 5), bahwa lembaga pendidikan dalam perspektif manajemen pendidikan dapat dikategorikan sebagai lembaga industry mulia (noble industry) karena mengemban misi ganda, yaitu profit sekaligus social. Misi profit, yaitu untuk mencapai keuntungan, ini dapat dicapai ketika efesiensi dan efektivitas dana bisa tercapai, sehingga pemasukan (income) lebih besar dari biaya operasional. Misi social bertujuan untuk mewariskan dan menginternalisasikan nilai luhur. Misi kedua ini dapat dicapai secara maksimal apabila lembaga pendidikan Islam tersebut memilki modal humancapital dan social capital yang memadai dan juga memiliki tingkat keefektifan dan efesiensi tinggi. Itulah sebabnya mengelola lembaga pendidikan Islam tidak hanya dibutuhkan profesionalisme yang tinggi tetapi juga misi niat-suci dan mental berlimpah.

\section{Pendidikan Multikultural}

Pendidikan multikultural berasal dari dua kata pendidikan dan multikultural. Pendidikan merupakan proses pengembangan sikap dan tata laku seseorang atau sekelompok orang dalam usaha mendewasakan manusia melalui pengajaran, pelatihan, proses, perbuatan dan cara-cara yang mendidik. Disisi lain pendidikan adalah transfer of knowledge atau memindah ilmu pengetahuan. Sedangkan multikultural secara etimologis multi berarti banyak, beragam dan aneka sedangkan kultural berasal dari kata culture yang mempunyai makna budaya, tradisi, kesopanan atau pemeliharaan. Rangkaian kata pendidikan dan multikutural memberikan arti secara terminologis adalah proses pengembangan seluruh potensi manusia yang menghargai pluralitas dan heterogenitasnya sebagai konsekwensi keragaman budaya, etnis, suku dan aliran (agama). Pendidikan multikultural adalah suatu cara untuk mengajarkan keragaman (teaching diversity) (Dirjen Pendis, 2016: 133)

\section{Pesantren}

Pesantren merupakan salah satu lembaga pendidikan swasta (non-pemerintah) yang para santrinya datang dari berbagai daerah dengan bermacam suku dan etnis. Para santridiwajibkan mukim atau tinggal di asrama dalam kehidupan sosio-multikultural. didalam pesantren terdapat kyai yang memimpin serta mengatur jadwal kegiatan santri yang dibantu oleh semacam biro pengasuhan santri atau pembina asrama. Pesantren terdiri dari berbagai 
macam diantaranya modern, salaf dan semi salaf. Perbedaan antara pesantren modern, pesantren salaf dan Pesantren semi salaf terletak pada kegiatan sehari-hari para santrinya.

Mengutip halaman darunnajah.com, di antara ciri-ciri pondok pesantren modern adalah; a) penekanan pada bahasa asing Arab dan Inggris dalam percakapan, b) memiliki sekolah formal dibawah kurikulum Diknas dan/atau Kemenag dari SD/MI MTS/SMP MA/SMA maupun sekolah tinggi, c) penguasaan atau porsi terhadap kitab kuning kurang, d) tidak lagi memakai sistem pengajian tradisional seperti sorogan, wetonan, dan bandongan, e) memakai buku-buku literatur bahasa Arab kontemporer (bukan klasik/kitab kuning), f) secara administratif mirip seperti administrasi sekolah formal, misalnya pendaftaran dengan sistem seleksi sehingga tidak semua calon santri diterima, biaya masuk umumnya lebih tinggi dari pesantren salaf, dan lain sebagainya, g) sisi kualitas keilmuan; berbahasa Arab percakapan lancar tapi kurang dalam kemampuan penguasaan literatur kitab kuning karya para ulama salaf dan gramatika bahasa Arab, serta penguasan terhadap disiplin ilmu keislaman (tafsir, ilmu hadits, fiqih, ushul fiqh dan lain sebagainya).

\section{Boarding school}

Sekolah berasrama (boarding school) merupakan lembaga pendidikan yang mengadopsi system pondok pesantren, walaupun bukan murni sebagaimana pondok pesantren yang ada. "Istilah boarding school mengandung pengertian "tempat tidur dan makan" atau "penginapan dan makan". Moris dalam (Laiser, 2016:1) mendefenisikan "a boarding school is a school in which most or all of the students live during the part of the year that they go to lessons. The word 'boarding' is used in the sense of "bed and board," i.e., lodging and meals".

Sebagai gambaran keistimewaan sekolah berasrama, di Amerika Serikat seperti, "Weston School", dalam perjalanannya memposisikan diri sebagai salah satu sekolah elit dan bergengsi. Siswa lulusan sekolah berasrama ini banyak diterima di Universitas favorit. Banyak politisi terkemuka, penulis sastra terkenal, akademisi dan intelektual terkemuka berasal dari sekolah berasrama Weston School ini(Ruben \&Fernandez, 2009:8).

Pada pertengahan tahun 1990-an kegelisaan sebagian besar masyarakat muslim Indonesia muncul akibat kondisi kualitas pendidikan bagi generasi bangsa yang cenderung terdikotomi secara ekstrim-yang pesantren terlalu keagamaan dan yang sekolah umum terlalu keduniawian - ada upaya untuk mengawinkan pendidikan umum dan pesantren dengan melahirkan term baru yang disebut boarding school. Sekolah berasrama atau boarding school ini bertujuan untuk melaksanakan pendidikan yang lebih komprehensif-holistik, ilmu dunia (umum) dapat dicapai dan ilmu agama juga dikuasai, maka sejak itu mulai bermunculan sekolah boarding yang didirikan seperti SMA Madania di Parung Bogor, SMA Al-Azhar di Lippo Cikarang, SMA Insan Cendekia di Serpong (sekarang MAN Insan Cendekia), SMA Dwiwarna di Parung Bogor, SMP dan SMA Al-Kautsar di Sukabumi, SMA Salman Al-Farisi, SMA IIBS di Lippo Cikarang (Muslimin, 2008).

\section{METODE PENELITIAN}

Penelitian ini adalah penelitian deskriptif kualitatif yang tertuju kepada pengungkapan atau menggambarkan suatu keadaan, masalah, peristiwa sebagaimana adanya secara sistematik. Dikatakan sebagai penelitian kualitatif dikarenakan dalam prosesnya peneliti melakukan observasi partisipatif untuk menguraikan, menggambarkan, menggali dan mendeskripsikan tentang pertanyaan-pertanyaan penelitian.

Karakteristik penelitian kualitatif menurut Bogdan and Biklen dalam (Sugiono, 2012:13) adalah; 1) dilakukan pada kondisi yang alamiah, 2) penelitian kualitatif lebih bersifat deskriptif. Data yang terkumpul berbentuk kata-kata atau gambar, sehingga tidak menekankan pada angka, 3) lebih menekankan pada proses daripada produk atau outcome, 4) analisa data secara induktif, dan 5) lebih menekankan makna (data dibalik yang teramati). 


\section{HASIL DAN PEMBAHASAN}

Studi multikulturalisme merupakan salah satu kajian ilmu politik. Studi ini sangat urgen pasca berakhirnya era kolonialisme dan imperialisme. Menyaksikan fenomena pada abad ke-20, studi tentang sistem politik, institusi pemerintahan, pemilihan umum, partai politik, dan parlemen masih mendominasi kalangan ilmuwan politik. Sementara kajian budaya politik, politik identitas, politik multikulturalisme, gender dan pendidikan multikulturalisme mulai banyak diminati, sebelumnya kajian ini cenderung menjadi kajian ilmuwan sosiologi, antropologi dan kajian ilmu Sejarah.

Kajian penelitian mengenai pendidikan multikulturalisme yang akan dilakukan ini, sebenarnya sudah cukup banyak dengan perspektif dan latar belakang keilmuan yang beragam. Paulo Freire merupakan salah satu penulis penting dan berpengaruh mengenai teori dan praktik pendidikan kritis abad ke-20. Fokusnya pada peran pendidikan dalam perjuangan kaum tertindas dicirikan dalam meramu dan mengawinkan konsep-konsep pendidikan yang sangat praktis untuk dikerjakan dalam rangka menuntas kebodohan di Brasil. Dalam kajiannya Freire menyatakan pendidikan bukan merupakan "menara gading" yang berusaha menjauhi realitas sosial dan budaya. Pendidikan menurutnya harus mampu menciptakan tatanan masyarakat yang terdidik dan berpendidikan, bukan sebuah masyarakat yang hanya mengagungkan prestis sosial sebagai akibat kekayaan dan kemakmuran yang dialaminya. Dari pendapat Freire tersebut dapat di fahami bahwa pendidikan multikultural bisa di maknai sebagai pendidikan untuk/tentang keragaman kebudayaan dalam merespon perubahan demografis dan kultural lingkungan masyarakat tertentu atau bahkan dunia secara keseluruhan. Pendidikan multikultural (multicultural education) merupakan respon terhadap perkembangan keragaman populasi sekolah, sebagaimana tuntutan persamaan hak bagi setiap kelompok. Dalam dimensi lain, pendidikan multikultural merupakan pengembang kurikulum dan aktivitas pendidikan untuk memasuki berbagai pandangan, sejarah, prestasi, dan perhatian terhadap terhadap orang-orang non Eropa.

Pendidikan multikultural merupakan proses pengembangan sikap dan tata laku seseorang atau sekelompok orang dalam usaha mendewasakan manusia melalui upaya pengajaran, pelatihan, proses, perbuatan, dan cara-cara mendidik yang menghargai pluralitas dan heterogenitas secara humanistik. Pendidikan adalah sebuah konsep, ide atau falsafah sebagai suatu rangkaian kepercayaan (set of believe) dan penjelasan yang mengakui dan menilai pentingnya keragaman budaya dan etnis di dalam membentuk gaya hidup, pengalaman sosial, identitas pribadi, kesempatan-kesempatan pendidikan dari individu, kelompok maupun negara. Tilaar mengemukakan gagasan mengenai pendidikan multikultural adalah sebagai tawaran konsep bagi dunia pendidikan Indonesia ke depan, khususnya pendidikan yang bercirikan Islam yang ada di Indonesia dalam hal ini adalah madrasah.

Satu penelitian lain yang penting dalam kajian ini adalah menjelaskan pendidikan multikultural merupakan proses pengembangan sikap dan tata laku seseorang atau sekelompok orang dalam usaha mendewasakan manusia melalui upaya pengajaran, pelatihan, proses, perbuatan, dan cara-cara mendidik yang menghargai pluralitas dan heterogenitas secara humanistik. Pendidikan adalah sebuah konsep, ide atau falsafah sebagai suatu rangkaian kepercayaan (set of believe) dan penjelasan yang mengakui dan menilai pentingnya keragaman budaya dan etnis di dalam membentuk gaya hidup, pengalaman sosial, identitas pribadi, kesempatan-kesempatan pendidikan dari individu, kelompok maupun negara. Tilaar mengemukakan gagasan mengenai pendidikan multikultural adalah sebagai tawaran konsep bagi dunia pendidikan Indonesia ke depan, khususnya pendidikan yang bercirikan Islam yang ada di Indonesia dalam hal ini adalah madrasah.

Pendidikan multikultural inilah yang akan mengantarkan dan membangun manusia Indonesia mempunyai jiwa nasionalisme dan akhirnya dapat mempertahankan keutuhan 
$\overline{\text { bangsa dari ancaman disintegrasi. Apabila diwujudkan oleh pendidikan bercorak keagamaan, }}$ maka pendidikan multikultural diyakini dapat mengantarkan peserta didik berpaham moderat dan inklusif. Menciptakan masyarakat semacam ini merupakan hal penting bagi bangsa Indonesia yang diketahui penduduknya multi-etnis, multi-agama,dan plura Internalisasi merupakan suatu proses penenaman nilai tentang budaya. Dalam penanaman dan penumbuhkembangan nilai tersebut dilakukan melalui berbagai didaktik-metodik pendidikan dan pengajaran, seperti pendidikan, pengarahan indoktrinasi, brainwashing, dan lain sebagainya. Internalisasi yaitu proses penyerapan nilai-nilai dan norma-norma oleh santri; proses belajar untuk berdaptasi terhadap keadaan, kondisi, dan lingkungan. Sedangkan kepribadian yaitu bahwa seseorang mempunyai beberapa ciri watak yang diperlihatkannya secara lahir, konsisten, dan konsekuen dalam tingkah lakunya sehingga tampak bahwa individu tersebut memiliki identitas khusus yang berbeda dari individu-individu lainnya. Gejala ini tumbuh berangsurangsur dalam keseharian santri diakibatkan oleh proses sosialisasi dan internalisasi. Selain itu, kepribadian seseorang juga dipengaruhi banyak hal.

Manfaat internalisasi adalah untuk pengembangan, perbaikan dan penyaringan dalam hal budaya. Dalam manfaat pengembangan memiliki manfaat sebagai pengembangan potensi seseorang untuk menjadi pribadi dan memiliki perilaku yang baik agar seseorang yang telah memiliki sikap dan perilaku yang mencerminkan budaya dan karakter khas pesantren. Pesantren sebagai institusi pendidikan Islam akan lebih efektif melakukan penanaman nilainilantradisi khas apabila santri melakukan enkulturasi penuh selama 24 jam, artinya santri melakukan aktiftas dan berada di pesantren sepanjang hari. Secara ideal jika santri pulang pada siang harinya sebagaimana sekolah pada umumnya, maka yang di dapatkan di rumah dan lingkungannya tidak boleh bertentangan dengan sekolah atau pesantrennya. Begitu pula dengan pesantren, dengan cara demikian pendidikan di pesantren akan berjalan efektif meskipun santri tidak menetap dipesantren. namun demikian hal ini akan bergantung kepada tingkat kepatuhan santri terhadap nilai yang di terapkan. Proses ini memerlukan waktu yang cukup sehingga nilai-nilai tradisi pesantren dapat di terima santri secara utuh.

\section{KESIMPULAN DAN SARAN}

Berdasarkan analisis di atas, maka dapat disimpulkan bahwa: Pertama, pola internalisasi tradisi di pondok sangat di pengaruhi oleh nilai-nilai karakter sosial siswa yang ada di pondok pesantren yang dapat ditanamkan pada pendidikan boarding shcool baik di pesantren maupun di madrasah. Kedua, pola tranformasi dimensi multikultural di pendidikan pesantren mempunyai ciri khas memberikan pengetahuan mengenai ilmu alat/metode, sebagai kunci untuk membaca dan memahami ilmu agama yang lebih mendalam, hal ini karena pemahaman mengenai ajaran agama dilandasi oleh pemahaman metodologis terhadap ilmu, pendidikan multikultural merupakan proses pengembangan sikap dan tata laku seseorang atau sekelompok orang dalam usaha mendewasakan manusia melalui upaya pengajaran, pelatihan, proses, perbuatan, dan cara-cara mendidik yang menghargai pluralitas dan heterogenitas secara humanistik

\section{DAFTAR RUJUKAN}

Laiser. (2016). The influence of boarding school to young children: A case of two boarding schools in Hai District in Kilimanjaro, Tanzania, Africa: University of Eastern Africa, International Journal of Education and Research, Vol. 4 No. 6.

Muhaimin et.al.(2009). Manajemen Pendidikan, Aplikasinya dalam Penyusunan Rencana Pengembangan Sekolah/Madrasah. Jakarta: Kencana.

Munir. (2016). Kultur Asrama Berbasis Sekolah Sebagai Pusat Pembinaan Karakter di SMPIT Al-Furqon Palembang, Jurnal Fakultas Tarbiyah dan Keguruan UIN Raden FatahPalembang. Intizar, Vol. 22, No. 2 
Papworth. (1998). Attending Boarding School: A longitudinal study of its role in Students' academic and non-academic Outcomes. Sydney: The University of Sydney.

Muslimin, Sutrisno. (2008). Problem Dan Solusi Pendidikan Di Sekolah Berasrama (Boarding School), https://sutris02.wordpress.com/2008/09/08/problem-dan-solusipendidikan-berasrama-boarding-school/.

Undang-undang Pesantren Nomor 18 Tahun 2019

Zainuddin. (2013). Pluralisme Agama dalam Analisis Kontruksi Sosial, Malang: UIN-Maliki Press. 